Lebensgemeinschaften der Landtiere

Ihre Erforschung unter Besonderer Berücksichtigung der Zoozönologischen Arbeitsmethoden. Von Dr. Janos Balogh. Zweite verbesserte und erweiterte ausgabe des 1953 erschienenen werkes "Grundzüge der Zoozönologie". Pp. ii +560 . (Budapest: Akdemiai Kiado, 1958.) n.p.

$\mathrm{T}$ HE Budapest school of terrestrial biology is well known for its work on the ecology of the soil fauna. Dr. J. Balogh's book is of value because it introduces this important work to a wider audience, but it is perhaps of even greater significance as a synthesis of theory and of methods of analysis eurrent in the different world schools of community ecology.

The first edition of this book was a stimulating and thoughtful analysis of animal synecology, logically beginning with definitions of the community (biozonose) and later departures from earlier concepts, followed by an analysis of the community, its detec. tion and delimitation, its structure and subdivision, its inorganic and living content, spatial and temporal changes, the food chain and production biology and finally a consideration of schemes of analysis and study in practical use. The new edition has been extended so that it is now an up-to-date and cosmopolitan account of this field. To this have now been added sections which provide the most extensive review now in print of methods for the collection, examination, eulture and extraction of terrestrial invertebrates, supplemented by sections on vertebrates by Turček and on agricultural land faunas by Heydemann (of Kiel). Although statistical aspects of sampling are not considered, no one who already works in this field can fail to find some useful details of technique which will be new to him, and no one entering the field could be referred to a more complete résumé of methods.

A. MACFADYEN

The Dawn of Life

By Dr. J. H. Rush. Pp. 258. (London: English Universities Press, Ltd., 1958.) 15s. net.

D R. J. H. RUSH has made a brave attempt to present a comprehensive account of the origins of living matter in terms intelligible to those without much knowledge of physics and chemistry. He has a rare skill for interpretation, and is adept both at choosing the right word and in using a suitable figure of speech for illuminating his text. Yet it is doubtful if his book can be called more than a gallant failure. Although the grand strategy is clear and well-conceived, the tactics are scarcely suitable to achieve the objective.

Besides descriptions of the hypothetical beginnings of the universe and the earth, the author includes accounts of the physico-chemical origin of living things, theories of evolution, life on other planets and the emergence of mind. All this, supported by the relevant laws of physies and a description of chemical theory, does not make for easy reading even for those with some knowledge of chemistry and physies. Like so many books intended for the general reader, the author has attempted too much in too short a space. If the first three chapters had been expanded and written with the intelligent secondary modern schoolboy in mind, Rush might well have produced an outstanding popular scientific work. He is to be congratulated for this attempt, and should be encouraged to write other popular works with the belief that sometimes greater clarification is achieved more by omission than commission.

T. H. Hawkins
An Introduction to Tropical Agriculture By Sir Harold Tempany and D. H. Grist. Pp. xvi $+347+12$ plates. (London and Now York: Longmans, Green and Co., Ltd., 1958.) 40s. net.

TWHE late Sir Harold Tempany has attempted "to provide a logical and coherent account of the background to agriculture in the tropics", which his co-author believes "should be of great value to students, agricultural officers and administrators" in these areas. Sir Harold, who had had a wide experience of tropical agriculture, died before completing his task, which was then entrusted to $\mathrm{Mr}$. D. H. Grist. With the increasing demand for tropical agricultural products and the urgent need to improve methods of land use and production and thereby raise the living standards of many tropical peoples, such a book should be very welcome, particularly as no such account had been published for some years. Unfortunately, the volume under review does not reach a standard adequate to meet this need.

The book is very uneven in content. Much space is wasted in explaining simple facts which are more adequately dealt with in the numerous elementary text-books on temperate agriculture. Thus a whole chapter is devoted to fertilizers in which the role of the major elements in plant nutrition and the nature of the common fertilizers are explained, while shifting cultivation, the most important system of farming in the tropics, with its wide range of variation and modern modifications, is dismissed in one page. The treatment of many subjects is so generalized, uncritical and superficial that it provides little information of practical value and some of it is inaccurate. It is possible to quote many statements of the obvious which might well have been omitted, such as "irregularities in the amount and incidence of rainfall cause great difficulties and these naturally increase as the drier regions are approached", which appears in almost identical words no less than three times in two consecutive pages.

J. W. Purseglove

\section{Flora of Manitoba}

By H. J. Scoggan. (National Museum of Canada Bulletin, No. 140.) Pp. v+619. (Ottawa: Queen's Printer, 1957.) 5 dollars.

THE province of Manitoba is larger than the 1 United Kingdom and is centrally placed in Canada both physically and botanically, but by a trick of fate it had remained uncovered by the three great manuals dealing with the flora of temperate North America. This neglect is now remedied by the excellent book under review. The major vegetation types of Manitoba are prairie (now mostly under cultivation), swamp and dry sandy forest near the Great Lakes, boreal forest, tundra forest and arctic tundra in the extreme north-east. These are briefly described, with their climates, and are illustrated by photographs. The rest of the book, apart from a bibliography, tabular classifications of species and lists of additions and exclusions, is the Flora proper, which follows many conventional lines.

There are no descriptions of individual taxa, and critical taxonomic comment is cut to the minimum, but the specific keys seem unusually ample and satisfactory, and there are many references to recent generic revisions. Careful notes are given on habitat and on distribution both within and outside the area, the "first report" of each taxon is always cited and so too, usually, are the "earliest collection seen" and the northernmost collection. Hybrids are omitted: 